\title{
CONCENTRATION LEVELS OF TRACE METALS IN FISH AND SEDIMENT FROM KUBANNI RIVER, NORTHERN NIGERIA
}

\author{
A. Uzairu $^{1 *}$, G.F.S. Harrison ${ }^{1}$, M. L. Balarabe ${ }^{2}$ and J.C. Nnaji ${ }^{3}$ \\ ${ }^{1}$ Department of Chemistry, Ahmadu Bello University, Zaria, Nigeria \\ ${ }^{2}$ Department of Biological Sciences, Ahmadu Bello University, Zaria, Nigeria \\ ${ }^{3}$ National Institute for Freshwater Fisheries Research, P. M. B. 6006, New-Bussa, Niger State, \\ Nigeria
}

(Received June 26, 2007; revised September 22, 2008)

\begin{abstract}
The concentrations of six trace metals ( $\mathrm{Pb}, \mathrm{Zn}, \mathrm{Cu}, \mathrm{Cr}, \mathrm{Ni}$ and $\mathrm{Cd}$ ) in fish and sediment samples from Kubanni River located in Zaria, Northern Nigeria, were investigated. The river receives agricultural runoff and municipal wastewaters, and is utilized for drinking, fishing and irrigation. Fractionation of trace metals in the river sediments, the risk to water column contamination and the levels of the six trace metals in Clarias gariepinus and Oreachromis niloticus samples were established. There was considerable risk to river water contamination based on the calculated individual trace metal average contamination factors (IACF) obtained for the river sediments from the trace metal sequential extractions. Also, the distribution and concentration of trace metals obtained in liver, gill, muscle and bone of $C$. gariepinus and $O$. niloticus showed that the human health risk for trace metals in muscles of fish were low, but individuals consuming fish livers might be at risk from ingestion of toxic metals at unacceptable concentrations.
\end{abstract}

KEY WORDS: Trace metals, Fish, Water, Sediment, Sequential extraction, Contamination factors, Kubanni River, Nigeria

\section{INTRODUCTION}

River water supports many life forms, provides recreation and fishing to the communities, and it may also be used for drinking purposes and irrigation. However, contamination of river water systems by trace metals is of major concern and their determination has received great attention for monitoring environmental pollution since the events of $\mathrm{Hg}$ and $\mathrm{Cd}$ poisoning through fish in Minamata, Japan [1-2].

Sediments are important sinks for various pollutants like trace metals and also play a considerable role in the remobilization of trace metals in aquatic systems under suitable conditions and in interactions between sediment and water column. The release of trace metals from sediments into the water body and consequently fish will depend on the chemical fractionation of metals and other factors such as sediment $\mathrm{pH}$, and the physical and chemical characteristics of the aquatic system [3]. Trace metals may distribute in sediments as exchangeable, acid soluble (bound to carbonates), reducible (bound to Fe/Mn oxides and hydroxides), oxidizable (bound to organic matter) and residual (bound to silicates and detrital materials) species. The chemical fractionation of trace metals in sediments can be investigated by carefully employing a selective extraction scheme from the several extraction schemes available in the literature.

Fish is a good source of protein and contains omega 3-fatty acids that help to reduce the risk of certain cancers [4-5] and cardiovascular disease [6]. Fish consumption is a major route of trace metal exposure for humans [7], and children are more at risk because of their greater intestinal absorptions [8].

Kubanni River originates in the precincts of the Ahmad Bello University (ABU) Main Campus, Zaria (Northern Nigeria), as a trench in an undulating agricultural land and is fed by a

*Corresponding author. E-mail: adamuuzairu@gmail.com 
number of tributaries (Figure 1). A dam, called ABU dam, was created on the river and serves as a source of water for drinking water production by the ABU water works. This river is also utilized for irrigation, fishing and general domestic application. Furthermore, Kubanni River drains the northwest zone of the city of Zaria and receives effluents mainly from domestic activity and runoff from intense cropping located in the adjoining land.

Quality of river water can be judged only by comparing concentrations of various constituents present in the river water. The analysis of fish or sediments of rivers are thus considered bio-indicators on the basis of which level of trace metals in the river water could be understood [9].

There is no data available yet on Kubanni River water quality and the health status of the river. Adverse effects of pollutants are supposed, when their concentrations exceed the maximum permissible limits. This study was, therefore, carried out to (i) assess risk of Kubanni River water contamination by river sediments; (ii) investigate the chemical fractionation of $\mathrm{Pb}$, $\mathrm{Zn}, \mathrm{Cu}, \mathrm{Cr}, \mathrm{Ni}$ and $\mathrm{Cd}$ in the river sediments because of their environmental implications; and (iii) determine the levels of the $\mathrm{Pb}, \mathrm{Zn}, \mathrm{Cu}, \mathrm{Cr}, \mathrm{Ni}$ and $\mathrm{Cd}$ metals in Clarias gariepinus and Oreachromis niloticus from Kubanni River because of the health implications to human populations consuming fishes from the river.

\section{EXPERIMENTAL}

\section{Quality assurance}

All the reagents used in this work were AnalaR grades from BDH Chemicals (UK) and double distilled and deionized (Milli-Q Gradient System, Millipore Corporation, USA) water was used throughout the experimentation except where indicated otherwise. Preparations of all the standard solutions were performed under clean laboratory environment. All the samples were digested along with blanks. Quantitation of metallic content of digested samples and blanks was carried out with the Pye-Unicam 969 atomic absorption spectrometer (UK) which was precalibrated using certified standards. To ensure that the Pye-Unicam 969 atomic absorption spectrometer remained calibrated during the experimentation, standards were analyzed after every 10 runs. The digestion methods used for fish tissues samples and the AAS analysis were also validated by spike recoveries using a multi-element standard solution (MESS). Sub-samples of oven-dried and grinded fish muscle and pooled liver were digested, run on AAS and metal contents in these un-spiked sub-samples determined from the calibration curve. Aliquots of the MESS were drawn with a graduated pipette and used to spike another set of oven-dried and grinded fish muscle and pooled liver sub-samples from the same original samples. The spiked sub-samples were then digested, run on AAS and metal contents determined from the calibration curve. (However, both un-spiked and spiked oven-dried and grinded fish muscle and pooled liver sub-samples were ashed before digestion). The amounts of spiked metals recovered after the digestion of the spiked sub-samples were used to calculate percentage recoveries. Finally, determinations of all parameters were carried out in triplicates per sample of fish tissues and sediments.

\section{Kubanni river sediment collection and analysis}

The location of Kubanni River is shown in Figure 1 along with the sampling points for sediment samples collected. Sediment samples were collected using pre-cleaned stainless steel Ekman dredge and immediately placed in plastic bags. Samples were transported to the laboratory and air-dried in the laboratory at room temperature. The air-dried sediment samples were then passed a $2 \mathrm{~mm}$ sieve and stored in acid washed polyethylene bottles with screw caps at room 
temperature. Sediment $\mathrm{pH}$ and electrical conductivity (EC) were measured in the slurry of $2 \mathrm{~mm}$ sieved air-dried sediment: water ratio of $1: 10 \mathrm{w} / \mathrm{v}$ using a pre-calibrated digital $\mathrm{pH}$ (HANNA, Model HI-991000, USA) and conductivity (HANNA, Model HI-99301, USA) meters. Readings were taken by inserting the electrodes of the $\mathrm{pH}$ and EC meters into the slurry after allowing it to stand for $30 \mathrm{~min}$ undisturbed. Organic matter content was determined by loss on ignition. Exchangeable cations were extracted by $0.1 \mathrm{M} \mathrm{BaCl}_{2}$ and subsequently determined by AAS [10]. Finally, three sediment sub-samples (one gram each) were subjected to a five step sequential extraction separately using the method of Shrivastava and Banerjee [11] as follows:

1. Exchangeable phase. Each sample was shaken at room temperature with $16 \mathrm{~mL}$ of $1 \mathrm{M}$ $\mathrm{Mg}\left(\mathrm{NO}_{3}\right)_{2}$ at $\mathrm{pH} 7.0$ for $1 \mathrm{~h}$, centrifuged and supernatant decanted and made up to $40 \mathrm{~mL}$ with double distilled and deionized water prior to analysis.

2. Oxidizable phase (bound to organic matter). Residue from $1+10 \mathrm{~mL}$ of $8.8 \mathrm{M} \mathrm{H}_{2} \mathrm{O}_{2}+6 \mathrm{~mL}$ of $0.02 \mathrm{M} \mathrm{HNO}_{3}$ was shaken for $5+1 \mathrm{~h}$ at $98{ }^{\circ} \mathrm{C} .10 \mathrm{~mL}$ of $3.5 \mathrm{M} \mathrm{CH}_{3} \mathrm{COONH}_{4}$ added as an extracting agent, centrifuged and supernatant made up to $40 \mathrm{~mL}$ with distilled water prior to analysis.

3. Acid soluble phase (bound to carbonates). $25 \mathrm{~mL}$ of $0.05 \mathrm{M} \mathrm{Na}_{2} \mathrm{EDTA}$ was added to the residue from 2 , shaken for $6 \mathrm{~h}$ and centrifuged. The supernatant was decanted and made to 40 $\mathrm{mL}$ with distilled water prior to analysis.

4. Reducible phase (bound to $\mathrm{Fe} / \mathrm{Mn}$ oxides and hydroxides). Residue from $3+17.5 \mathrm{~mL}$ of 0.1 $\mathrm{M} \mathrm{NH} 2 \mathrm{OH} \cdot \mathrm{HCl}+17.5 \mathrm{~mL}$ of $3.5 \mathrm{M} \mathrm{CH}_{3} \mathrm{COONH}_{4}$ were shaken for $4+1 \mathrm{~h}$ at $98{ }^{\circ} \mathrm{C}$. Extracted with $10 \mathrm{~mL}$ of $3.5 \mathrm{M} \mathrm{CH}_{3} \mathrm{COONH}_{4}$, shaken for $1 \mathrm{~h}$, centrifuged, the supernatant decanted and made up to $40 \mathrm{~mL}$ with distilled water prior to analysis.

5. Residual phase (bound to silicates and detrital materials). Residue from 4 was digested by using aqua regia/hydrofluoric acid $\left(\mathrm{HCl}-\mathrm{HNO}_{3} / \mathrm{HF}\right)(0.35: 12 \mathrm{w} / \mathrm{v}$ sediment/solution ratio) in acid digestion Teflon cup. It was dry ashed for $2 \mathrm{~h}$ and evaporated to dryness. The residue was diluted to $40 \mathrm{~mL}$ with distilled water prior to analysis.

After each successive extraction, the samples were centrifuged at $4500 \mathrm{rpm}$ for $15 \mathrm{~min}$ [12]. The supernatants were removed with pipette and filtered with Whatman No. 42 filter paper. The residue was washed with deionized water followed by vigorous hand shaking and then followed by $15 \mathrm{~min}$ of centrifugation before the next extraction. The volume of rinsed water was kept to a minimum to avoid excessive solubilization of solid materials. Finally, the extracts collected were analyzed using AAS to determine the concentrations of $\mathrm{Pb}, \mathrm{Zn}, \mathrm{Cu}, \mathrm{Cr}, \mathrm{Ni}$ and $\mathrm{Cd}$ metals.

\section{Fish collection and analysis}

Five samples of Clarias gariepinus and Oreachromis niloticus each, the most common types of fish in Kubanni River and widely consumed, were caught with fishing net. The fish samples obtained were kept on ice in the field and transported to the laboratory. In the laboratory, fish samples were frozen until ready for analysis. The methods of Hodson et al. [13] and APHA [14] were used to determine levels of $(\mathrm{Pb}, \mathrm{Zn}, \mathrm{Cu}, \mathrm{Cr}, \mathrm{Ni}$ and $\mathrm{Cd})$ trace metals in fish tissues as follows: wet weight of liver, gill, muscle and bone was carried out using an acid-washed, preweighted dry crucible. The tissues were oven-dried at $60{ }^{\circ} \mathrm{C}$ for $48 \mathrm{~h}$, ground and ashed at 450 ${ }^{\circ} \mathrm{C}$ for $12 \mathrm{~h}$ until white ash was formed. Digestion of the samples was carried out based on the methods of APHA [14] using conc. $\mathrm{HNO}_{3}$ (70 \% AR, BDH, UK). The levels of $\mathrm{Pb}, \mathrm{Zn}, \mathrm{Cu}, \mathrm{Cr}$, $\mathrm{Ni}$ and $\mathrm{Cd}$ in digests were then determined using the AAS. 


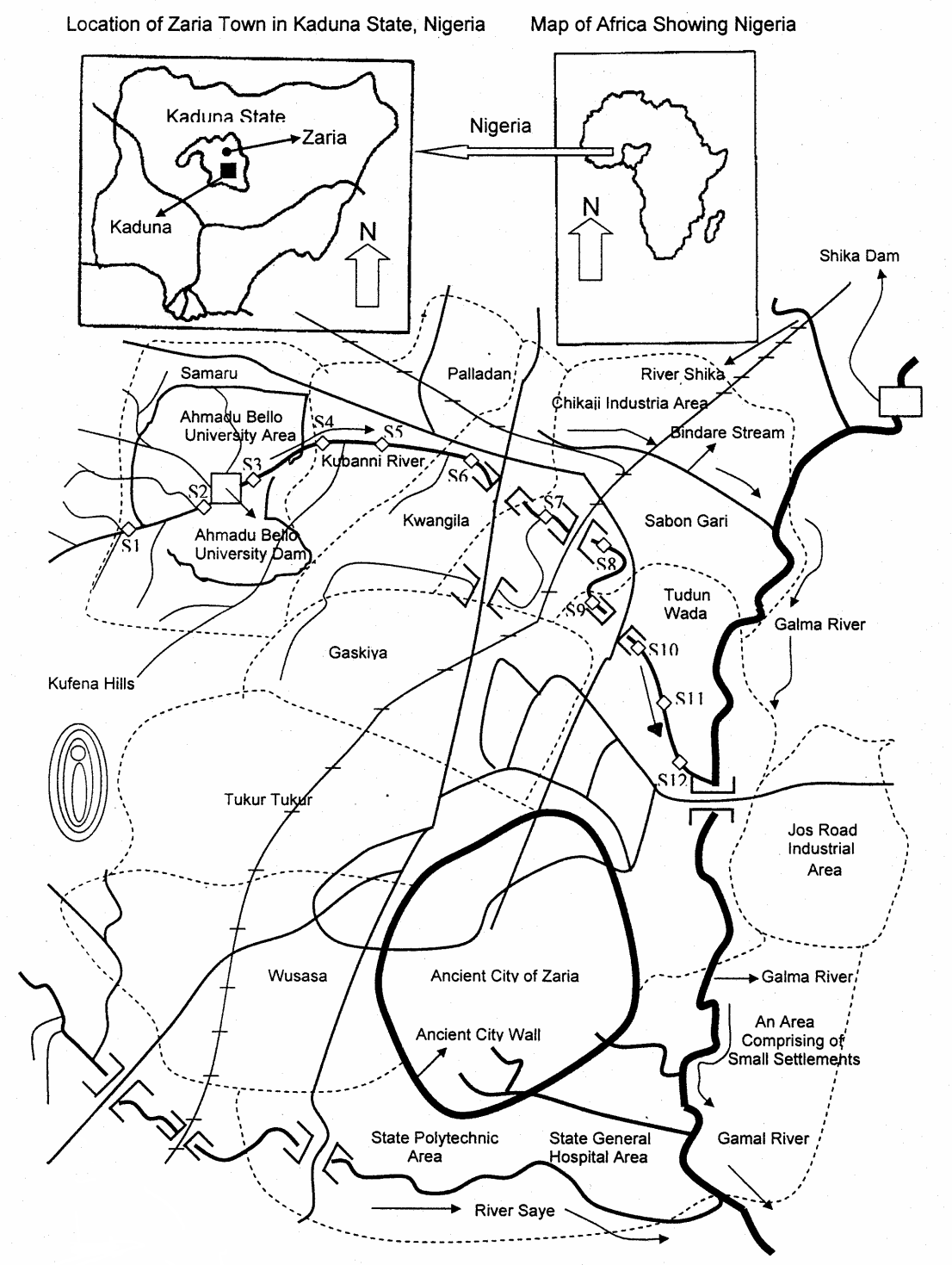

Figure 1. Map of Zaria Town and location of sampling points S1 - S12 along the Kubanni River.

\section{RESULTS AND DISCUSSION}

Quality assurance

Results of the recoveries of spiked fish muscle and pooled liver samples are given in Table 1. Percentage recoveries obtained for the metals under investigation $(\mathrm{Pb}, \mathrm{Zn}, \mathrm{Cu}, \mathrm{Cr}, \mathrm{Ni}$ and $\mathrm{Cd})$ varied between $92.25 \pm 3.28-101.56 \pm 4.03$. Acceptable recoveries were obtained in all cases, 
which show that the digestion method used for fish tissues samples and the AAS analysis were reliable.

Table 1. Mean percentage recoveries $( \pm$ SD) of trace metals from spiked fish muscle and pooled liver samples.

\begin{tabular}{|c|c|c|c|c|}
\hline $\begin{array}{l}\text { Trace } \\
\text { metal }\end{array}$ & Spike level & $\begin{array}{l}\text { Expected concentration in } \\
\text { spiked sample digest } \\
\left(\mathrm{mgL}^{-1}\right)\end{array}$ & $\begin{array}{l}\text { Observed concentration } \\
\text { in spiked sample digest } \\
\qquad\left(\mathrm{mgL}^{-1}\right)\end{array}$ & $\%$ Recovery \pm SD \\
\hline $\mathrm{Pb}$ & \multirow{6}{*}{$\begin{array}{l}30 \mathrm{~mL} \text { of }\left(1.8 \mathrm{mg} \mathrm{L}^{-1}\right. \\
\text { of } \mathrm{Pb} \text { and } \mathrm{Cd} ; 3 \mathrm{mg} \\
\mathrm{L}^{-1} \text { of } \mathrm{Cr} \text { and } \mathrm{Ni} ; 5 \\
\left.\mathrm{mg} \mathrm{L}^{-1} \text { of } \mathrm{Zn} \text { and } \mathrm{Cu}\right) \\
\text { multi-element } \\
\text { standard solution }\end{array}$} & 1.080 & 1.012 & $93.69 \pm 1.95$ \\
\hline $\mathrm{Zn}$ & & 3.000 & 3.047 & $101.56 \pm 4.03$ \\
\hline $\mathrm{Cu}$ & & 3.000 & 2.929 & $97.62 \pm 2.92$ \\
\hline $\mathrm{Cr}$ & & 1.800 & 1.735 & $96.40 \pm 2.45$ \\
\hline $\mathrm{Ni}$ & & 1.800 & 1.701 & $94.48 \pm 3.37$ \\
\hline $\mathrm{Cd}$ & & 1.080 & 0.996 & $92.25 \pm 3.28$ \\
\hline
\end{tabular}

*Average of six observations from three replicate analyses of each of fish muscle and pooled liver spiked samples.

\section{Chemical fractionation of trace metals in Kubanni River sediments}

The results of the chemical fractionation of trace metals in Kubanni River sediments and some physico-chemical characteristics of the sediments are given in Table 2 . The study reveals that the river sediments were alkaline in nature with an average $\mathrm{pH}$ of 9.65. The organic matter and electrical conductivity were found to be $10.35 \%$ and $0.35 \mathrm{mScm}^{-1}$, respectively. Also, the CEC determined by the sum of $0.1 \mathrm{M} \mathrm{BaCl}_{2}$ exchangeable cations was found to be $114.72 \mathrm{mg} / 100 \mathrm{~g}$ and $\mathrm{Ca}$ was the dominant exchangeable cation $(53.24 \pm 13.84)$.

The data obtained by the sequential extraction procedure indicates the following trace metal distribution pattern:

$\mathrm{Pb}$ : residual $>$ reducible $>$ acid soluble $>$ exchangeable $>$ oxidizable

Zn: residual $>$ oxidizable $>$ reducible $>$ acid soluble $>$ exchangeable

$\mathrm{Cu}$ : residual $>$ acid soluble $>$ oxidizable $\approx$ exchangeable $>$ reducible

Cr: residual $>$ oxidizable $>$ reducible $\approx$ exchangeable $>$ acid soluble

Ni: residual $>$ oxidizable $>$ reducible $>$ exchangeable $>$ acid soluble

$\mathrm{Cd}$ : residual $>$ reducible $>$ oxidizable $>$ acid soluble $>$ exchangeable .

The non-residual fraction, for all the trace metals, contained more than $37 \%$ of the total extractable metals. All the trace metals, except $\mathrm{Cr}$, were mostly associated with the non-residual fractions of the sediments and reflect the greater tendency of the metals to become available to water column. The study also showed that the sedimentary matrix (residual phase) of the river sediments contained significant fractions of the trace metals. The residual fraction represents metals largely embedded in the crystal lattice of the sediments and should not be available for remobilization except under very harsh conditions. $\mathrm{Pb}$ and $\mathrm{Cd}$ were largely associated with residual and reducible species in the sediments. Fe/Mn oxides (reducible phase) exist as nodules, concretions, cement between particles, or as coating on particles and are trace element excellent scavengers [15]. On the other hand, the oxidizable fraction of $\mathrm{Pb}$ is only $2.6 \%$, in agreement with the fact that alkaline $\mathrm{pH}$ condition does not favour the sorption of $\mathrm{Pb}$ by organic matter in sediments [16]. $\mathrm{Cu}$ existed mostly as residual and acid soluble species. The acid soluble fraction is influenced by $\mathrm{pH}$ and the observed $\mathrm{pH}$ of the sediments was 9.65 , which does not favour the release of metals into water column from this fraction. Lastly, $\mathrm{Zn}, \mathrm{Cr}$ and $\mathrm{Ni}$ 
existed mostly as residual and oxidizable forms. Under oxidizing conditions, metals present in both natural organic matter and living organisms may be remobilized into the aquatic environment. $\mathrm{Zn}, \mathrm{Cr}$ and $\mathrm{Ni}$ removal requires strong acid condition and may not therefore be available for remobilization into water column since sediments were alkaline.

Table 2. Chemical fractionation of trace metals in Kubanni River sediments and some physico-chemical characteristics of the sediments.

\begin{tabular}{|c|c|c|c|c|c|c|c|c|c|}
\hline \multirow{2}{*}{\multicolumn{3}{|c|}{$\begin{array}{l}\text { Physico-chemical } \\
\text { parameter }\end{array}$}} & \multicolumn{7}{|c|}{ Trace metal fraction ( $\mathrm{mg} \mathrm{kg}^{-1}$ dry weight) } \\
\hline & & & \multirow{2}{*}{$\begin{array}{l}\text { Exchangea } \\
\text { ble }\end{array}$} & \multirow{2}{*}{\begin{tabular}{|l|}
$\mathrm{Pb}$ \\
$1.63 \pm 0.29$
\end{tabular}} & \multirow{2}{*}{\begin{tabular}{|l|}
$\mathrm{Zn}$ \\
$5.43 \pm 0.93$
\end{tabular}} & \multirow{2}{*}{\begin{tabular}{|l|}
$\mathrm{Cu}$ \\
$5.39 \pm 0.92$ \\
\end{tabular}} & \multirow{2}{*}{$\begin{array}{l}\mathrm{Cr} \\
2.75 \pm 0.61\end{array}$} & \multirow{2}{*}{$\begin{array}{l}\mathrm{Ni} \\
2.04 \pm 0.80\end{array}$} & \multirow{2}{*}{$\frac{\mathrm{Cd}}{0.20 \pm 0.07}$} \\
\hline $\mathrm{pH}$ & & $9.65 \pm 0.42$ & & & & & & & \\
\hline $\begin{array}{l}\mathrm{EC} \\
(\mathrm{mS} \mathrm{cm}\end{array}$ & & $0.35 \pm 0.09$ & $\begin{array}{l}\text { Oxidizable } \\
\text { (bound to } \\
\text { organic } \\
\text { matter) }\end{array}$ & $0.44 \pm 0.20$ & $15.80 \pm 3.00$ & $5.82 \pm 1.31$ & $3.82 \pm 0.85$ & $4.72 \pm 1.63$ & $0.65 \pm 0.28$ \\
\hline $\begin{array}{l}\text { Organic } \\
(\%)\end{array}$ & matter & $10.35 \pm 2.04$ & \begin{tabular}{|l|} 
Acid \\
soluble \\
(bound to \\
carbonates) \\
\end{tabular} & $2.67 \pm 0.90$ & $11.26 \pm 1.74$ & $12.76 \pm 2.40$ & $1.54 \pm 0.41$ & $1.85 \pm 0.47$ & $0.49 \pm 0.16$ \\
\hline Ex-Na & $\begin{array}{l}(\mathrm{mg} \\
\text { per } \\
100 \mathrm{~g} \\
\text { dry } \\
\text { weig }\end{array}$ & $9.54 \pm 1.98$ & \begin{tabular}{|l|} 
Reducible \\
(bound to \\
Fe/Mn \\
oxides \& \\
hydroxides) \\
\end{tabular} & \begin{tabular}{|l|}
$4.71 \pm 1.03$ \\
\end{tabular} & $12.92 \pm 1.43$ & $3.48 \pm 0.74$ & $2.80 \pm 1.03$ & $3.90 \pm 1.51$ & $1.14 \pm 0.40$ \\
\hline Ex-K & ht) & $26.80 \pm .67$ & \begin{tabular}{|l|} 
Residual \\
(bound to \\
silicates \\
\& detrital \\
materials) \\
\end{tabular} & $7.53 \pm 2.48$ & $33.71 \pm 4.10$ & $24.98 \pm 4.15$ & $18.32 \pm 3.17$ & $7.43 \pm 2.11$ & $2.17 \pm 1.05$ \\
\hline Ex-Mg & & $20.73 \pm 4.51$ & $\%$ & 44.35 & 42.61 & 47.64 & 62.68 & 37.26 & 46.67 \\
\hline $\mathrm{Ex}-\mathrm{Ca}$ & & $53.24 \pm 13.84$ & \begin{tabular}{|l|} 
Non- \\
residual
\end{tabular} & 9.45 & 45.41 & 27.45 & 10.91 & 12.51 & 2.48 \\
\hline Ex-Fe & & $3.02 \pm 0.51$ & $\%$ & 55.65 & 57.39 & 52.36 & 37.32 & 62.74 & 53.33 \\
\hline Ex-Mn & & $1.40 \pm 0.36$ & $\begin{array}{l}\text { Total } \\
\text { extractable }\end{array}$ & 16.98 & 79.12 & 52.43 & 29.23 & 19.94 & 4.65 \\
\hline$\sum_{\text {cations }}$ & & 114.72 & & & & & & & \\
\hline
\end{tabular}

Note: (i) Non-residual fraction is the sum of exchangeable, oxidizable, acid soluble and reducible fractions. (ii) Total extractable trace metal is the sum of all five fractions for the metal. (iii) All data reported as mean with one standard deviation (SD).

Total extractable trace metals from Kubanni River sediments, their individual average contamination factors (IACF) and other global published values for rivers sediments are presented in Table 3. The data obtained shows that the trend of occurrence of the trace metals in the river sediments was: $\mathrm{Zn}>\mathrm{Cu}>\mathrm{Cr}>\mathrm{Ni}>\mathrm{Pb}>\mathrm{Cd}$. The values got in this study for these metals were higher than the corresponding values for Tyume River [17] and Calcasieu River/Lake [18]. However, the levels of $\mathrm{Pb}$ and $\mathrm{Zn}$ reported by Ellaway et al. [19] for sediments of Yarra River/Estuary (Australia) were higher than the corresponding Kubanni River values.

Table 3 also shows the calculated individual average contamination factors (IACF) for the six trace metals analyzed in Kubanni River sediments. The IACF for each metal in the river was calculated from the result of the fractionation study by dividing the sum of the first four fractions (i.e. the exchangeable, carbonate bound, Fe/Mn oxides and hydroxides forms and the oxidizable forms) by the residual fraction for the River and reflects the risk of contamination of a water body by a pollutant. The higher the levels of the mobilizable fractions (i.e. 
exchangeable, acid soluble, reducible and oxidizable trace metals) in the sediments, the higher the potential risk to river water contamination by river sediment. The remobilization of trace metals from the river sediment into water column will be affected by factors such as $\mathrm{pH}$, chemical forms of the trace metals, and physico-chemical characteristics of the water column. The IACF values found were generally significant, with $\mathrm{Ni}$ posing the highest risks to river water contamination. $\mathrm{Cr}$ posed the lowest risks to water contamination followed by $\mathrm{Cu}, \mathrm{Cd}, \mathrm{Pb}$ and $\mathrm{Zn}$.

Table 3. Total extractable trace metals from Kubanni River sediments, their individual contamination factors (ICF) in the river and published mean sediment values in some countries $\left(\mathrm{mg} \mathrm{kg}^{-1}\right.$ dry weight).

\begin{tabular}{|l|c|c|c|c|c|c|}
\hline Trace metal & $\mathrm{Pb}$ & $\mathrm{Zn}$ & $\mathrm{Cu}$ & $\mathrm{Cr}$ & $\mathrm{Ni}$ & $\mathrm{Cd}$ \\
\hline This work & 16.98 & 79.12 & 52.43 & 29.23 & 19.94 & 4.65 \\
\hline $\begin{array}{l}\text { Yarra river } \\
\text { Australia [27] }\end{array}$ & 43 & 122 & 64 & & & \\
\hline $\begin{array}{l}\text { Yarra estuary } \\
\text { Australia [27] }\end{array}$ & 375 & 447 & 106 & & & \\
\hline $\begin{array}{l}\text { Calcasieu river/lake } \\
\text { LA USA [26] }\end{array}$ & 9.90 & 35.6 & 6.91 & 19.1 & & 0.98 \\
\hline $\begin{array}{l}\text { Tyume river } \\
\text { S/Africa [19] }\end{array}$ & $0.040-0.067$ & $0.080-0.491$ & $0.082-0.496$ & & $0.401-0.981$ & trace-0.005 \\
\hline IACF $^{\text {c }}$ & 1.26 & 1.35 & 1.10 & 0.60 & 1.68 & 1.14 \\
\hline $\begin{array}{l}\text { Sediment quality } \\
\text { guidelines (mg kg }\end{array}$ & & & & & \\
\hline LELs $^{\text {a }}$ ) & 31 & 120 & 16 & 26 & 16 & 0.6 \\
\hline SQS $^{\text {b }}$ & 450 & 410 & 390 & 260 & & 5.1 \\
\hline
\end{tabular}

${ }^{a}$ LELs: Lowest levels in provincial. Sediment quality guidelines by the Ontario Ministry of Environment and Energy. ${ }^{b} \mathrm{SQS}$ : Sediment quality standards used as sediment quality goal for Washington State sediments (http://www.ecy.wa.gov/PROGRAMS/tcp/smu/sed_Chem.htm). ${ }^{c} \mathrm{IACF}=$ sum of (exchangeable, oxidizable, acid soluble and reducible) fractions/residual fraction for the river.

Currently, Nigeria has set no guideline values on the levels of trace metals in sediments of freshwater resources. With the view to making preliminary evaluation of the risks of contamination of Kubanni River sediments by trace metals, comparison was made with sediment quality standards of other countries. For example, all the six trace metals extracted from Kubanni River sediments were lower than the corresponding values of Sediment Quality Standards for Washington State (SQS). However, $\mathrm{Cu}, \mathrm{Cr}$, Ni and $\mathrm{Cd}$ were higher than the Ontario (Canada) Ministry of Environment and Energy Provincial Sediment Quality Guidelines Lowest Effect Levels (LELs).

Trace metals in Kubanni River fish samples

The mean values of the six trace metals ( $\mathrm{mg} \mathrm{kg}^{-1}$ wet weight) evaluated in pooled liver, gills, muscle and bone of $C$. gariepinus and $O$. niloticus collected from Kubanni River are shown in Table 4. The distribution of the trace metals varied as follows:

Clarias gariepinus: $\mathrm{Pb}, \mathrm{Cr}$ and $\mathrm{Cd}$ : liver $>$ gill $>$ bone $>$ muscle; $\mathrm{Zn}$ : liver $>$ bone $>$ gill $>$ muscle; $\mathrm{Cu}$ : liver $>$ gill $>$ muscle $>$ bone; and Ni: gill $>$ bone $>$ liver $>$ muscle .

Oreachromis niloticus: $\mathrm{Pb}, \mathrm{Ni}, \mathrm{Zn}$ and $\mathrm{Cu}$ : liver $>$ gill $>$ bone $>$ muscle; $\mathrm{Cr}$ : gill $>$ liver $>$ bone $>$ muscle; and $\mathrm{Cd}$ : liver $>$ gill $>$ bone $\approx$ muscle. 
Table 4. Mean $( \pm \mathrm{SD})$ of trace metals $\left(\mathrm{mg} \mathrm{kg}^{-1}\right.$ wet weight $)$ in Kubanni River fish samples.

\begin{tabular}{|l|l|c|c|c|c|c|c|}
\hline Fish & Tissue type & $\mathrm{Pb}$ & $\mathrm{Zn}$ & $\mathrm{Cu}$ & $\mathrm{Cr}$ & $\mathrm{Ni}$ & $\mathrm{Cd}$ \\
\hline $\begin{array}{l}\text { Clarias } \\
\text { gariepinus }\end{array}$ & Liver & $0.28 \pm 0.10$ & $49.56 \pm 8.21$ & $19.31 \pm 2.55$ & $12.50 \pm 1.51$ & $1.05 \pm 0.36$ & $0.21 \pm 0.08$ \\
\cline { 2 - 8 } & Gill & $0.12 \pm 0.04$ & $20.05 \pm 3.74$ & $1.87 \pm 0.15$ & $2.78 \pm 0.30$ & $2.41 \pm 0.28$ & $0.13 \pm 0.02$ \\
\cline { 2 - 8 } & Muscle & $0.04 \pm 0.01$ & $4.92 \pm 1.50$ & $0.24 \pm 0.02$ & $0.40 \pm 0.03$ & $0.92 \pm 0.06$ & $0.02 \pm 0.00$ \\
\cline { 2 - 8 } & Bone & $0.09 \pm 0.03$ & $21.90 \pm 4.13$ & $0.16 \pm 0.02$ & $1.08 \pm 0.22$ & $1.27 \pm 0.11$ & $0.04 \pm 0.01$ \\
\hline \multirow{3}{*}{$\begin{array}{l}\text { Oreachromis } \\
\text { niloticus }\end{array}$} & Liver & $0.76 \pm 0.13$ & $65.72 \pm 7.76$ & $40.11 \pm 6.00$ & $7.85 \pm 1.42$ & $3.21 \pm 0.24$ & $0.40 \pm 0.10$ \\
\cline { 2 - 8 } & Gill & $0.24 \pm 0.11$ & $26.14 \pm 3.28$ & $5.32 \pm 1.47$ & $10.63 \pm 2.74$ & $2.76 \pm 0.18$ & $0.08 \pm 0.02$ \\
\cline { 2 - 8 } & Muscle & $0.02 \pm 0.00$ & $7.61 \pm 1.83$ & $1.15 \pm 0.38$ & $0.68 \pm 0.14$ & $0.03 \pm 0.00$ & $0.02 \pm 0.01$ \\
\cline { 2 - 8 } & Bone & $0.15 \pm 0.06$ & $16.49 \pm 2.51$ & $3.49 \pm 0.75$ & $0.47 \pm 0.09$ & $1.13 \pm 0.08$ & $0.03 \pm 0.01$ \\
\hline FAO $\left(\mathrm{mg} \mathrm{kg}^{-1}\right)^{\mathrm{a}}$ & 0.5 & 30 & 30 & & & 0.5 \\
\hline Health criteria $\left(\mathrm{mg} \mathrm{kg}^{-1}\right)^{\mathrm{b}}$ & 4 & 480 & 120 & 8 & & \\
\hline CCFAC ML $\left(\mathrm{mg} \mathrm{kg}^{-1}\right)^{\mathrm{c}}$ & 0.2 & & & & & 0.5 \\
\hline
\end{tabular}

${ }^{\text {a }}$ ref. [28]; ${ }^{\text {bref. [27]; }}{ }^{c}$ ref. [29].

Generally, the levels of trace metals in the liver and gills irrespective of the type of fish were higher than the results obtained for bone and muscle. The higher level of trace metals in the liver relative to other tissues may be attributed to the high coordination of metallothionein protein with the metals [20]. In addition, the liver is the principal organ responsible for the detoxification, transportation, and storage of toxic substances and it is an active site of pathological effects induced by contamination [21]. The gills perform the function of respiration and are directly in contact with water and pollutants that may be present in water. Thus, the concentrations of trace metals in gills reflect the concentration of trace metals in the waters where the fish lives [22]. Annune and Iyaniwura [23] also reported the liver of O. niloticus and C. gariepinus to have accumulated $\mathrm{Zn}$ and $\mathrm{Cd}$ more than other tissues. Similarly, the low levels of trace metals in muscle tissues of both $C$. gariepinus and $O$. niloticus observed in this study agree with the findings of Brooks and Rumsey [24], Badsha and Goldspink [25], Oladimeji and Offem [26], and Annune and Iyaniwura [23] who studied the bioaccumulation of trace metals in several fish species including $C$. gariepinus and $O$. niloticus.

The mean levels of $\mathrm{Pb}, \mathrm{Zn}, \mathrm{Cu}$, and $\mathrm{Cd}$ in muscle, gill and bone of both $C$. gariepinus and $O$. niloticus were below the health criteria established by the United States Environmental Protection Agency (US EPA) for human health risk for carcinogens [27], Food and Agriculture Organization (FAO) maximum limits [28] and Codex Committee on Food Additives and Contaminants maximum levels (CCFAC) [29]. However, pooled mean $\mathrm{Pb}, \mathrm{Zn}, \mathrm{Cu}$ and $\mathrm{Cr}$ levels in liver of the two fish species analyzed exceeded the US EPA, FAO and CCFAC guidelines in general. Thus there may be some concern for individuals consuming fish livers.

\section{CONCLUSIONS}

The health status of Kubanni River with respect to water column contamination by trace metals in the river sediments and quality of fish caught from the river for human consumption was evaluated in this study. Based on the calculated individual trace metal average contamination factors (IACF) obtained for the River sediments from the trace metal fractionation study, risk to water contamination by metals was significant. Also, risks from consumption of fish muscles were low since the levels of all the trace metals in fish muscles analyzed were below their corresponding US EPA, FAO and CCFAC permissible limits. However, individuals consuming fish livers may face considerable risk from ingestion of toxic metals at unacceptable concentrations. Finally, this work may provide valuable database for future research on Kubanni River. 


\section{REFERENCES}

1. Mason, C.F. Biology of Fresh Water Pollution, 3rd ed., Longman: London; 1996; pp 367377.

2. Meyer, E. Chemistry of Hazardous Materials, Prentice-Hall: Eaglewood Cliffs; 1977; pp 205-207.

3. Morgan, J.J.; Stumm, W. Chemical processes in the environment, relevance of chemical speciation, in Metals and their compounds in the environment Merien, E. (Ed.), VCH Publishers: Berlin; 1991; pp 67-103.

4. Terry, P.; Wolk, A.; Vainio, H.; Weiderpass, E. Cancer Epidemiol. Biom. Prevent. 2002, 11, 143.

5. Terry, P.; Lichtenstein, P.; Feychting, M.; Ahlbom, A.; Wolk, A. Lancet. 2001, 357, 1764.

6. La Vecchia, C.; Chaatenoud, L.; Altieri, A.; Tavari, A. Nutr. Metabol. Cradiov. Dis. 2001, $11,10$.

7. Dougherty, C.P.; Henricks Holtz, S.; Reinert, J.C.; Panyacosit, I.; Axelrad, D.A.; Woodruff, T. J. Environ. Res. 2000, 84, 170.

8. Chance, G.W.; Harmsen, E. Can. J. Public Health 1998, 89, S10.

9. Jaleel, T.; Jaffar, M.; Ashraf, M. Toxicol. Env. Chem. U.K. 1993, 33, 133.

10. Hendershot, W.H.; Duquette, M. Soil Sci. Soc. Am. J. 1986, 50, 605.

11. Shrivastava, S.K.; Banergee, D.K. Water, Air, and Soil Pollution 2004, 152, 219.

12. Legret, M.; Diver, L.; Juste, C. Water Res. 1988, 22, 953.

13. Hodson, P.V.; Blunt, B.R.; Spry, D.J. Water Res. 1978, 12, 869.

14. APHA (American Public Health Association, American Water Works Association and Water Pollution Control Federation) Standard Methods for the Examination of Waters and Wastewaters, 16th ed. APHA: New York; 1985; p 1193.

15. Jenne, E.A. Adv. Chem. Ser. 1968, 73, 337.

16. Baruah, N.K.; Kotoky, P.; Bhattacharyya, K.G.; Borah, G.C. Sci. Total Environ. 1996, 193, 1.

17. Awofolu, O.R.; Mbolekwa, Z.; Mtshemla, V.; Fatoki, O.S. Water SA, 2005, 31, 87.

18. Beck, J.N.; Ramelow, G.J.; Thompson, R.S.; Mueller, C.S.; Webre, C.L.; Young, J.C.; Langley, M.P. Hydrobiologia 1990, 192, 149.

19. Ellaway, M.; Hart, B.T.; Beckett, R. Australian J. Mar. Freshwater Res. 2005, 33, 761.

20. Friberg, L.; Piscator, M; Northberg, G. Cadmium in the Environment, Chemical Rubber G: Cleveland; 1971.

21. Evans, D.W.; Dodoo, D.K.; Hanson, P.J. Mar. Pollut. Bull. 1993, 26, 329.

22. Romeo, M.; Siau, Y.; Sidoumou, Z.; Gnassia-Barelli, M. Sci. Total Environ. 1999, 232, 169.

23. Annune, P.A.; Iyaniwura, T.T. J. Aquat. Food Prod. Technol. 1993, $2,5$.

24. Brooks, R.R.; Rumsey, D. NZ J. Mar. Freshwater Res. 1974, 8, 155.

25. Badsha, K.S.; Goldspink, C.R. J. Fish Biol. 1982, 21, 251.

26. Oladimeji, A.A.; Offem, B.O. Water, Air, and Soil Pollution, 1989, 44, 191.

27. US EPA (United States Environmental Protection Agency) Methods for Chemical Analysis of Water and Wastewater, EPA Report 600/4-79-020, Office of Water, Cincinnati, Ohio; 1983.

28. FAO (Food and Agriculture Organization) Compilation of legal limits for hazardous substances in fish and fishery products, FAO Fishery Circular No. 463; 1983; pp 5-100.

29. CCFAC (Codex Committee on Food Additives and Contaminants) Comments submitted on draft maximum levels for lead and cadmium. Agenda 16c/16d, joint FAO/WHO Food Standards Programme, Thirty-third session, The Hague, The Netherlands; 12-16 March 2001. 